Gut, 1982, 23, 974-979

\title{
Antidiarrhoeal activity of loperamide: studies of its influence on ion transport across rabbit ileal mucosa in vitro
}

\author{
S HUGHES, N B HIGGS, and L A TURNBERG* \\ From the Department of Medicine, Hope Hospital (University of Manchester School of Medicine), Salford
}

SUMMARY Loperamide is a well-established antidiarrhoeal agent with effects on gastrointestinal motility. We have now shown that the drug influences ion transport. In isolated rabbit ileal mucosa loperamide caused a dose-related fall in potential difference and short-circuit current and reduced the serosa to mucosa flux of chloride. The electrical effects were inhibited by naloxone $\left(10^{-6} \mathrm{M}\right)$ suggesting that they were mediated by opiate receptors. Loperamide $\left(10^{-6} \mathrm{M}\right)$ inhibited secretion provoked by heat stable and heat labile $E$. coli toxins and by prostaglandin $\mathrm{E}_{2}$. We conclude that loperamide is able to inhibit secretion mediated by cAMP or cGMP, and that this may be relevant to its antidiarrhoeal properties.

The antidiarrhoeal activity of opiates has long been thought to depend on their ability to influence intestinal motility. The recent demonstration, however, that morphine and certain enkephalins can influence ion transport across intestinal epithelium has prompted a re-examination of this hypothesis. Morphine enhances absorption of chloride across isolated rabbit ileal mucosa ${ }^{1}$ and inhibits secretion provoked by a variety of secretagogues, ${ }^{2}$ so that this antisecretory activity may be at least partly responsible for the antidiarrhoeal effect.

The commonly used antidiarrhoeal drug loperamide is an opiate derivative, which does not have central nervous system effects. ${ }^{3}$ Like morphine it has been thought to exert its actions through effects on intestinal motility ${ }^{4}$ but we demonstrate here that it also has antisecretory effects in isolated rabbit ileum.

\section{Methods}

Details of the methods used have been described previously ${ }^{5}$ but, briefly, male New Zealand white rabbits $(2$ to $4 \mathrm{~kg}$ ) were killed by air embolus and the distal ileum rapidly removed and bathed in oxygenated Ringer's bicarbonate buffer. Mucosa stripped of muscle layers was mounted in modified

* Address for correspondence: Professor L A Turnberg, Department of Medicine, Hope Hospital (University of Manchester School of Medicine), Eccles Old Road, Salford M6 8HD, UK.

Received for publication 21 February 1982
Ussing chambers ${ }^{6}$ and bathed on each side by $10 \mathrm{ml}$

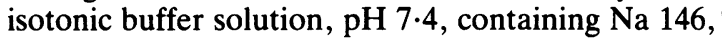
$\mathrm{K} 4 \cdot 2, \mathrm{Cl} 125 \cdot 8, \mathrm{HCO}_{3} 26 \cdot 6, \mathrm{H}_{2} \mathrm{PO}_{4} 0 \cdot 2, \mathrm{HPO}_{4} 1 \cdot 2$, $\mathrm{Ca} 1 \cdot 2, \mathrm{Mg} 1 \cdot 2$, and glucose $10 \mathrm{mmol} / 1$. The buffer was stirred and oxygenated via a bubble lift mechanism by a $95 \% \mathrm{O}_{2} / 5 \% \mathrm{CO}_{2}$ mixture and maintained at $37^{\circ} \mathrm{C}$.

\section{ELECTRICAL MEASUREMENTS}

The transmucosal potential difference and shortcircuit current were measured as described previously ${ }^{5}$ and the electrical resistance calculated.

\section{RADIO-ISOTOPIC FLUXES}

Sodium and chloride fluxes were measured using 0.5 $\mu \mathrm{Ci}{ }^{22} \mathrm{Na}$ and $2.5 \mu \mathrm{Ci}^{36} \mathrm{Cl}$ (Radiochemical Centre, Amersham) added to either mucosal or serosal reservoirs 20 minutes after mounting the tissue. After a further 20 minute equilibration period serial $1 \mathrm{ml}$ samples were taken at 20 minute intervals, and replaced with $1 \mathrm{ml}$ unlabelled buffer solution.

Eight pieces of mucosa from one rabbit were mounted in each experiment and these were paired provided that their resistances differed by less than $25 \% .{ }^{7}$ Unidirectional and net fluxes and residual ion fluxes were calculated as described previously. ${ }^{5}$

Pure loperamide hydrochloride powder was dissolved in Ringer's bicarbonate buffer with ethanol $(4 \mathrm{ml} / \mathrm{l})$ to improve solubility. The final ethanol concentration in the test and control chambers was $0.004 \%$. 
In each experiment, after 20 minutes for equilibration, ion fluxes were determined over a 20 minute control period and then during three consecutive 20 minute flux periods after the addition of the drug or, to the controls, ethanol. In experiments with heat-labile $E$. coli toxin, which has a delayed action, the toxin was left in contact with the mucosa for 70 minutes before the three 20 minute flux periods began; loperamide was added 30 minutes before these flux periods. In experiments with prostaglandin $\mathrm{E}_{2}$ or heat-stable $E$. coli toxin the secretagogue and loperamide were added simultaneously after the control flux period, immediately before the first of the three 20 minute flux periods. In each instance control fluxes were compared with the third flux period after loperamide.

Loperamide was kindly provided by Janssen Pharmaceuticals Ltd and the E. coli toxins by Dr B Drasar, London School of Hygiene and Tropical Medicine. Naloxone was obtained from Winthrop Laboratories and $\mathrm{PGE}_{2}$ from Sigma Chemical Co.

All values are expressed as the mean \pm 1 SEM. Statistical comparisons were performed using Student's $t$ test for paired data. Values were held to be significant if $\mathrm{p}<0.05$.

\section{Results}

ELECTRICAL RESPONSES TO LOPERAMIDE

After a 20 minute period of stabilisation the potential difference and short-circuit current of control tissues remained relatively constant, falling slowly by less than $1 \%$ in 10 minutes $(n=20)$ while tissue resistance remained unchanged. Loperamide $10^{-7}$ and $10^{-6} \mathrm{M}$ on the serosal side significantly reduced potential difference and short-circuit current $(p<0.01)$ (Fig. 1) but left tissue resistance unchanged. The reduction at $10^{-8} \mathrm{M}$ was not statistically significant $(\mathrm{p} 0 \cdot 15)$. Loperamide $10^{-6} \mathrm{M}$ had no effect when added to the mucosal side (Fig. 2). Pretreatment with naloxone $10^{-6} \mathrm{M}$, inhibited the fall in potential difference and short-circuit current induced by serosal loperamide $10^{-6} \mathrm{M}(\mathrm{p}<0.02)$ (Fig. 2), suggesting that loperamide exerted these electrical effects via opiate receptors.

\section{RADIO-ISOTOPE FLUXES}

Loperamide $10^{-6} \mathrm{M}$ reduced the serosa to mucosa chloride flux but had no significant effect on net chloride movement $(p 0.5)$. Short-circuit current was reduced but residual ion flux was unchanged (Table 1).

\section{INFLUENCE OF LOPERAMIDE ON INTESTINAL}

SECRETION

Prostaglandin $E_{2}\left(P G E_{2}\right)$

Serosally applied $\mathrm{PGE}_{2}\left(10^{-5} \mathrm{M}\right)$ increased potential difference, short-circuit current $(\mathrm{p}<0.001)$, and tissue resistance $(p<0 \cdot 01)$, the peak response occurring within 10 minutes. Simultaneous addition of loperamide $10^{-6} \mathrm{M}$ did not influence the electrical response to $\mathrm{PGE}_{2}$
Fig. 1 Effect on short-circuit current (Isc) of varying concentrations of loperamide on the serosal surface of rabbit ileal mucosa in vitro. Loperamide or control buffer was added as indicated by arrow.

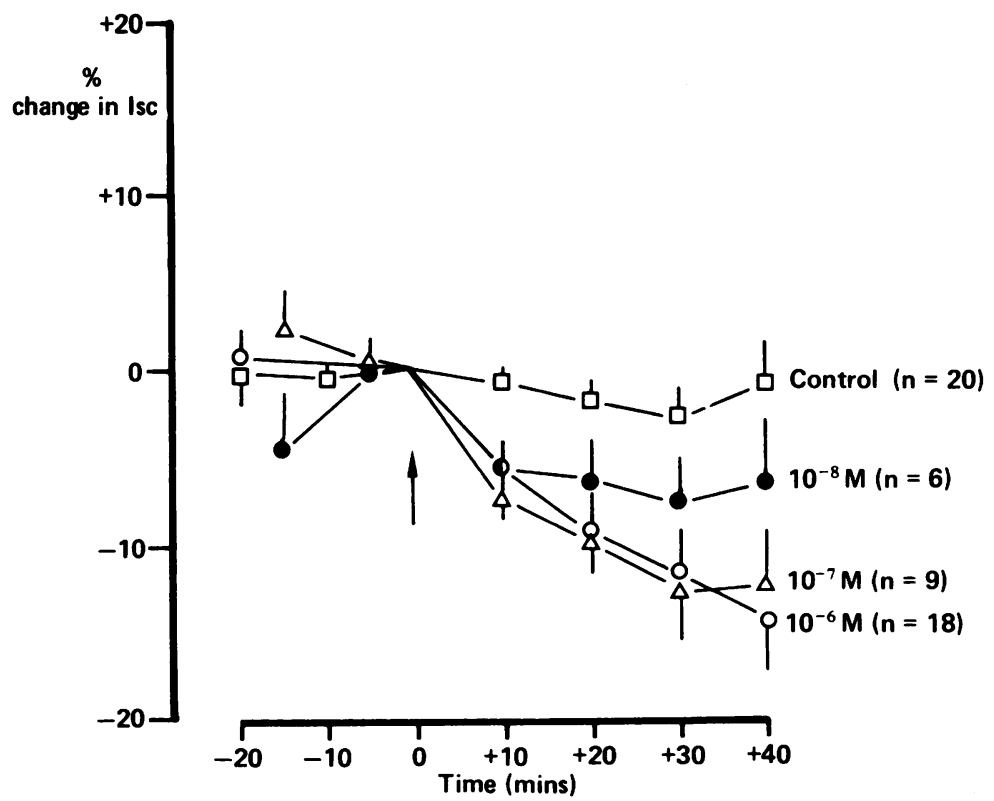


Fig. 2 Influence of loperamide $\left(10^{-6} \mathrm{M}\right)$ on shortcircuit current (Isc) when added to the mucosal or the serosal sides of rabbit ileal mucosa. The effect of naloxone added at point $A$ on the response to serosal loperamide is shown. Loperamide or control buffer was added as indicated by arrow.

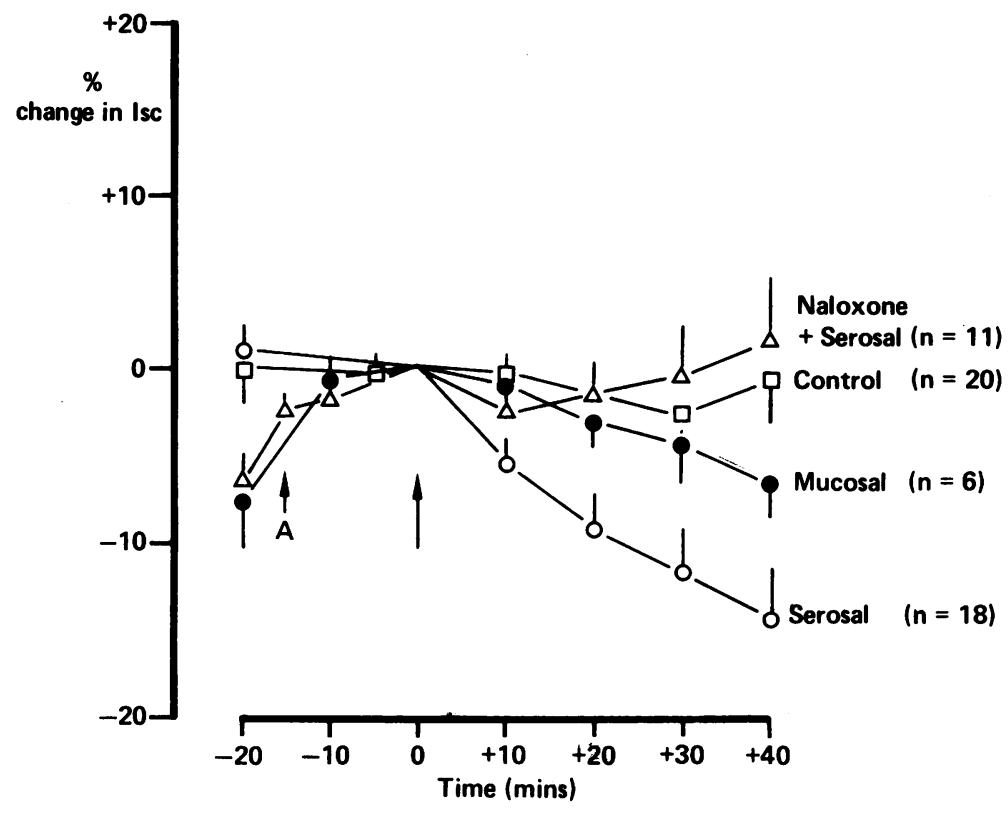

Heat-labile E. coli toxin

The addition of $200 \mu \mathrm{l}$ of a crude toxin-containing medium to the mucosal side of control tissues increased potential difference and short-circuit current within 10 minutes, increasing further over the next two hours. Loperamide $\left(10^{-6} \mathrm{M}\right)$ added 40 minutes after the toxin did not significantly influence this electrical response.

Unidirectional flux determinations 110 to 130 minutes after toxin addition showed a reduced net

Table 1 Unidirectional and net $\mathrm{Na}$ and $\mathrm{Cl}$ fluxes over 20 minute periods immediately before and from 20 to 40 minutes after addition of $(A)$ control solution or $(B)$ loperamide

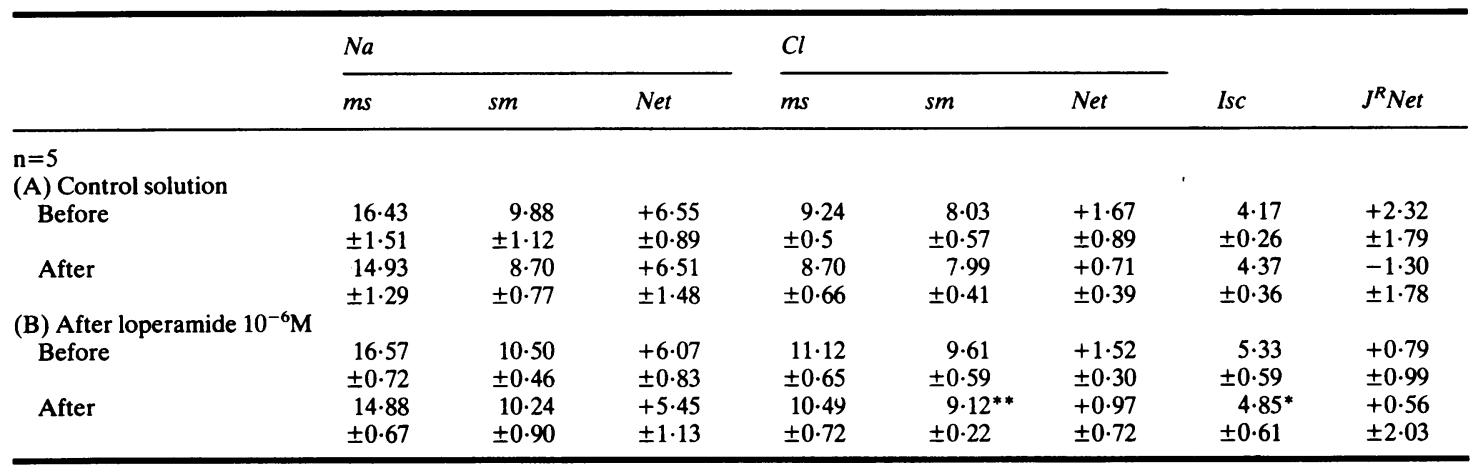

Fluxes in $\mu \mathrm{mol}(\mu \mathrm{Eq}) / \mathrm{cm}^{2} / \mathrm{h}$. $+=$ net absorption. $-=$ net secretion. $\mathrm{ms}=$ mucosa to serosa flux. sm $=$ serosa to mucosa flux. Isc $=$ short-circuit current $. \mathrm{J}^{\mathrm{R}} \mathrm{Net}=$ residual ion flux.

${ }^{* *} \mathrm{p}<0 \cdot 02 .{ }^{*} p<0 \cdot 05$. Significance of difference between flux periods before, and after addition of control or loperamide solution. Differences between fluxes not indicated by asterisks were not statistically significant - that is, $p \geqslant 0 \cdot 1$. 
Table 2 Unidirectional and net $\mathrm{Na}$ and $\mathrm{Cl}$ fluxes over 20 minute periods immediately before and from 40 to 60 minutes after addition of $(A) P G E_{2}$ or $(B) P G E_{2}+$ loperamide

\begin{tabular}{|c|c|c|c|c|c|c|c|c|}
\hline & \multirow[b]{2}{*}{$m s$} & \multicolumn{3}{|l|}{$\mathrm{Na}$} & \multicolumn{3}{|l|}{$\mathrm{Cl}$} & \multirow[b]{2}{*}{$J^{R}$ Net } \\
\hline & & $s m$ & Net & $m s$ & $s m$ & Net & $I s c$ & \\
\hline \multicolumn{9}{|l|}{$n=6$} \\
\hline Control & $\begin{array}{r}18.34 \\
\pm 1.64\end{array}$ & $\begin{array}{r}11 \cdot 19 \\
\pm 0.93\end{array}$ & $\begin{array}{l}+7 \cdot 14 \\
\pm 0.97\end{array}$ & $\begin{array}{l}11 \cdot 6 \\
\pm 0 \cdot 48\end{array}$ & $\begin{array}{r}9.72 \\
\pm 0.67\end{array}$ & $\begin{array}{l}+1.89 \\
\pm 0.7\end{array}$ & $\begin{array}{r}5.02 \\
\pm 0.76\end{array}$ & $\begin{array}{l}-0.23 \\
\pm 1.07\end{array}$ \\
\hline $\mathrm{PGE}_{2}$ & $\begin{array}{l}14.04^{*} \\
\pm 0.94\end{array}$ & $\begin{array}{r}11.64 \\
\pm 0.75\end{array}$ & $\begin{array}{l}+2.39 * * \\
\pm 1.07\end{array}$ & $\begin{array}{r}10.44 \\
\pm 0.34\end{array}$ & $\begin{array}{l}11.55^{*} \\
\pm 1.28\end{array}$ & $\begin{array}{l}-1.20^{* * *} \\
\pm 0.99\end{array}$ & $\begin{array}{l}6 \cdot 73^{* * *} \\
\pm 0.87\end{array}$ & $\begin{array}{l}+3 \cdot 15^{*} \\
\pm 0.88\end{array}$ \\
\hline \multicolumn{9}{|l|}{$\begin{array}{l}n=9 \\
\text { (B) }\end{array}$} \\
\hline Control & $\begin{array}{r}17 \cdot 88 \\
\pm 1 \cdot 10\end{array}$ & $\begin{array}{r}10.73 \\
\pm 0.93\end{array}$ & $\begin{array}{l}+7 \cdot 16 \\
\pm 0 \cdot 88\end{array}$ & $\begin{array}{r}10.54 \\
\pm 0.51\end{array}$ & $\begin{array}{r}8.24 \\
\pm 0.26\end{array}$ & $\begin{array}{l}+2.29 \\
\pm 0.48\end{array}$ & $\begin{array}{r}5.16 \\
\pm 1.72\end{array}$ & $\begin{array}{l}+0.30 \\
\pm 1.01\end{array}$ \\
\hline $\mathrm{PGE}_{2}+$ loperamide $10^{-6} \mathrm{M}$ & $\begin{array}{r}15.69 \\
\pm 0.97\end{array}$ & $\begin{array}{r}10.22 \\
\pm 0.60\end{array}$ & $\begin{array}{l}+5.47^{* * *}+ \\
\pm 0.82\end{array}$ & $\begin{array}{r}10.72 \\
\pm 0.84\end{array}$ & $\begin{array}{l}9.64^{* * * *} \\
\pm 0.54\end{array}$ & $\begin{array}{l}+1.08 \\
\pm 0.92\end{array}$ & $\begin{array}{r}6.08 \\
\pm 0.64\end{array}$ & $\begin{array}{l}+1.69 \\
\pm 1.07\end{array}$ \\
\hline
\end{tabular}

Fluxes in $\mu \mathrm{mol}(\mu \mathrm{Eq}) / \mathrm{cm}^{2} / \mathrm{h}$. $+=$ net absorption. $-=$ net secretion. $\mathrm{ms}=$ mucosa to serosa flux. $\mathrm{sm}=$ serosa to mucosa flux. Isc $=$ short-circuit current. $\mathrm{J}^{\mathrm{R}} \mathrm{Net}=$ residual ion flux.

${ }^{* * *} p<0 \cdot 01 .{ }^{* *} p<0 \cdot 02$. ${ }^{*} p<0 \cdot 05$. Significance of difference from its paired control. $+p<0 \cdot 025-$ significance of difference from response to $\mathrm{PGE}_{2}$ alone.

sodium absorption, due to a decrease in mucosa to serosa flux, and a net chloride secretion due to a reduction in the mucosa to serosa chloride flux. Loperamide $\left(10^{-6} \mathrm{M}\right)$ added 40 minutes after the toxin - that is, 30 minutes before flux determinations - reduced these flux responses (Table 3 ).

\section{Heat-stable E. coli toxin}

Addition of $200 \mu \mathrm{l}$ of a crude toxin-containing medium to the mucosal side caused an immediate increase in potential difference and short-circuit current but left tissue resistance unchanged. Similar electrical effects were obtained using a similar medium without toxin. Loperamide $\left(10^{-6} \mathrm{M}\right)$ added simultaneously did not modify the electrical response to the toxin.

The control medium had no effect on sodium or chloride fluxes but the toxin solution decreased net sodium absorption by reducing the mucosa to serosa and increasing the serosa to mucosa sodium fluxes, although neither of the unidirectional flux changes were individually significant. The toxin almost abolished net chloride absorption because of an increase in serosa to mucosa chloride flux. Simultaneous addition of loperamide $\left(10^{-6} \mathrm{M}\right)$ to the serosal side prevented the changes in chloride transport induced by the toxin on the mucosal side but sodium absorption was still reduced (Table 4).

Table 3 Unidirectional and net $\mathrm{Na}$ and $\mathrm{Cl}$ fluxes over 20 minute periods immediately before and from 70 to 90 minutes after addition of $(A) E$. coli heat-labile toxin or $(B) E$. coli heat-labile toxin + loperamide

\begin{tabular}{|c|c|c|c|c|c|c|c|c|}
\hline & \multirow[b]{2}{*}{$m s$} & \multicolumn{3}{|l|}{$\mathrm{Na}$} & \multicolumn{3}{|l|}{$\mathrm{Cl}$} & \multirow[b]{2}{*}{$J^{R} \mathrm{Net}$} \\
\hline & & $s m$ & Net & $m s$ & $s m$ & Net & Isc & \\
\hline \multicolumn{9}{|l|}{$\begin{array}{l}n=6 \\
\text { (A) }\end{array}$} \\
\hline Control & $\begin{array}{r}13.54 \\
\pm 0.98\end{array}$ & $\begin{array}{r}8.39 \\
\pm 0.59\end{array}$ & $\begin{array}{l}+5 \cdot 14 \\
\pm 0 \cdot 76\end{array}$ & $\begin{array}{r}10.43 \\
\pm 0.70\end{array}$ & $\begin{array}{r}8.45 \\
\pm 0.40\end{array}$ & $\begin{array}{l}+1.98 \\
\pm 0.90\end{array}$ & $\begin{array}{r}3.55 \\
\pm 0.22\end{array}$ & $\begin{array}{l}+0.39 \\
\pm 0.67\end{array}$ \\
\hline Heat-labile toxin & $\begin{array}{l}11.01^{*} \\
\pm 1.37\end{array}$ & $\begin{array}{r}9.06 \\
\pm 0.70\end{array}$ & $\begin{array}{l}+1.96^{* * *} \\
\pm 0.99\end{array}$ & $\begin{array}{c}8.66^{*} \\
\pm 0.82\end{array}$ & $\begin{array}{r}10 \cdot 16 \\
\pm 0.70\end{array}$ & $\begin{array}{l}-1.49^{*} \\
\pm 0.72\end{array}$ & $\begin{array}{l}4 \cdot 78^{* *} \\
\pm 0.47\end{array}$ & $\begin{array}{l}+1.33 \\
\pm 0.82\end{array}$ \\
\hline $\begin{array}{l}n=6 \\
\text { (B) }\end{array}$ & & & & & & & & \\
\hline Control & $\begin{array}{r}13.61 \\
\pm 1.81\end{array}$ & $\begin{array}{r}9.39 \\
\pm 0.85\end{array}$ & $\begin{array}{l}+4.25 \\
\pm 1.04\end{array}$ & $\begin{array}{r}11.66 \\
\pm 1.04\end{array}$ & $\begin{array}{r}9.92 \\
\pm 0.68\end{array}$ & $\begin{array}{l}+1.74 \\
\pm 1.06\end{array}$ & $\begin{array}{r}4.76 \\
\pm 0.82\end{array}$ & $\begin{array}{l}+2.25 \\
\pm 1.01\end{array}$ \\
\hline Heat-labile toxin + loperamide & $\begin{array}{r}13 \cdot 10 \\
\pm 1.33\end{array}$ & $\begin{array}{r}10.37 \\
\pm 1.02\end{array}$ & $\begin{array}{l}+3.46 \\
\pm 1.43\end{array}$ & $\begin{array}{r}10.61 \\
\pm 1.27\end{array}$ & $\begin{array}{r}10.93 \\
\pm 1.70\end{array}$ & $\begin{array}{l}-0.32 \\
\pm 0.83\end{array}$ & $\begin{array}{r}6.13 \\
\pm 1.21\end{array}$ & $\begin{array}{l}+2.74 \\
\pm 0.94\end{array}$ \\
\hline
\end{tabular}

Fluxes in $\mu \mathrm{mol}(\mu \mathrm{Eq}) / \mathrm{cm}^{2} / \mathrm{h} .+=$ net absorption. $-=$ net secretion. $\mathrm{ms}=$ mucosa to serosa flux. sm $=$ serosa to mucosa flux. Isc $=$ short-circuit current. $\mathrm{J}^{\mathrm{R}} \mathrm{Net}=$ residual ion flux. ${ }^{* * *} \mathrm{p}<0 \cdot 01 .{ }^{* *} \mathrm{p}<0 \cdot 02 .{ }^{*} \mathrm{p}<0.05$. 
The toxin caused an increase in short-circuit current but not residual ion flux, whereas toxin and loperamide together caused an increase in both short-circuit current and residual ion flux (Table 4).

\section{Discussion}

Loperamide is a butyramide derivative and an opiate agonist ${ }^{8}$ which improves the diarrhoea due to many causes. ${ }^{9-14}$ It has profound effects on intestinal motility causing a dose-related inhibition of longitudinal and circular muscle activity during pressureinduced peristaltic reflexes in guinea-pig isolated ileum. ${ }^{15}$ It slows the progression of ingested charcoal through the gastrointestinal tract of mice. ${ }^{3}$ The antidiarrhoeal effect of loperamide was attributed to these actions on motility. ${ }^{4}$ The observations that prostaglandin and bisacodyl-induced secretion in rats was inhibited by loperamide, ${ }^{10} 17$ however, and that atropine, although moderately effective in reducing peristalsis, is not an effective antidiarrhoeal agent ${ }^{16}$ suggest that loperamide may also have effects on intestinal absorption or secretion. Sandhu et al ${ }^{18}$ showed that pretreating rats with loperamide inhibited secretion induced in vivo by cholera toxin and prostaglandin $\mathrm{E}_{2}$ supporting this possibility. Our data in vitro clearly indicate that loperamide inhibits the secretion provoked by three different types of secretagogue in an isolated preparation of ileal mucosa where effects on motility can be entirely obviated. These results are in keeping with recent reports from this laboratory ${ }^{12}$ and elsewhere ${ }^{1920}$ that opiates affect intestinal absorption and inhibit secretion. Morphine stimulated chloride absorption under basal conditions ${ }^{1}$ and inhibited the secretion due to cholera toxin, prostaglandin $\mathrm{E}_{2}$, or acetylcholine. ${ }^{2}$

In the present study, loperamide did not influence net transport in unstimulated tissue, although it reduced serosa to mucosa chloride fluxes. Loperamide, however, slightly reduced the potential difference and short-circuit current in these tissues, and presumably the ion transport effects, which must have accompanied this electrical response, were small and difficult to detect by our technique. There is little doubt, however, that loperamide inhibits the actively secreting mucosa. Prostaglandin $\mathrm{E}_{2}$ and heat labile $E$. coli toxin stimulate secretion by activating cAMP production, ${ }^{21} 22$ while heat stable $E$. coli toxin is believed to exert its effect by stimulating cGMP production. ${ }^{23}$ Thus the antisecretory effect of loperamide cannot be explained simply by inhibition of one of these nucleotides alone. The increased cAMP content of intestinal mucosa after cholera toxin stimulation was not inhibited by loperamide in one study, ${ }^{18}$ suggesting that the antisecretory effect was exerted at a site distal to the activation of cAMP; this may be a site common to both cAMP and cGMP.

Naloxone inhibited the electrical effects of

Table 4 Unidirectional and net $\mathrm{Na}$ and $\mathrm{Cl}$ fluxes over 20 minute periods immediately before and from 60 to 80 minutes after addition of $(A)$ toxin-free control medium, $(B)$ E. coli heat-stable toxin and $(C)$ toxin + loperamide

\begin{tabular}{|c|c|c|c|c|c|c|c|c|}
\hline & \multirow[b]{2}{*}{$m s$} & \multicolumn{3}{|l|}{$\mathrm{Na}$} & \multicolumn{3}{|l|}{$\mathrm{Cl}$} & \multirow[b]{2}{*}{$J^{R} N e t$} \\
\hline & & $s m$ & Net & $m s$ & $s m$ & Net & Isc & \\
\hline \multicolumn{9}{|l|}{$\begin{array}{l}n=5 \\
\text { (A) }\end{array}$} \\
\hline \multirow[t]{2}{*}{ Control } & 16.95 & $11 \cdot 30$ & $+5 \cdot 66$ & $12 \cdot 46$ & $10 \cdot 58$ & +1.88 & $4 \cdot 27$ & +0.49 \\
\hline & \pm 1.77 & \pm 1.06 & $\pm 0 \cdot 82$ & $\pm 0 \cdot 88$ & $\pm 1 \cdot 14$ & \pm 0.93 & \pm 0.75 & \pm 0.34 \\
\hline \multirow[t]{2}{*}{ Control medium } & $17 \cdot 25$ & $10 \cdot 30$ & $+7 \cdot 55$ & $13 \cdot 17$ & $10 \cdot 83$ & +2.97 & $5 \cdot 59$ & $-1 \cdot 24$ \\
\hline \multirow{2}{*}{\multicolumn{9}{|c|}{$\begin{array}{l}n=8 \\
\text { (B) }\end{array}$}} \\
\hline & & & & & & & & \\
\hline \multirow{2}{*}{ Control } & $15 \cdot 89$ & 9.90 & $+7 \cdot 24$ & 11.99 & 10.09 & $+2 \cdot 70$ & $4 \cdot 88$ & -0.46 \\
\hline & $\pm 2 \cdot 26$ & \pm 0.97 & $\pm 1 \cdot 23$ & $\pm 1 \cdot 13$ & $\pm 0 \cdot 52$ & \pm 0.72 & \pm 0.69 & $\pm 0 \cdot 87$ \\
\hline \multirow[t]{2}{*}{ Heat-stable toxin } & $14 \cdot 13$ & $10 \cdot 52$ & $+4 \cdot 86^{*}$ & $11 \cdot 59$ & $11 \cdot 48^{*}$ & $+0.53^{* *}$ & $6 \cdot 23^{* *}$ & +0.72 \\
\hline & $\pm 2 \cdot 14$ & \pm 0.83 & $\pm 1 \cdot 54$ & \pm 1.03 & $\pm 0 \cdot 91$ & $\pm 0 \cdot 80$ & $\pm 1 \cdot 00$ & $\pm 1 \cdot 27$ \\
\hline \multicolumn{9}{|l|}{$\begin{array}{l}n=5 \\
\text { (B) }\end{array}$} \\
\hline \multirow[t]{2}{*}{ Control } & $16 \cdot 55$ & 9.43 & $+7 \cdot 73$ & $12 \cdot 32$ & $9 \cdot 35$ & +2.98 & $4 \cdot 28$ & +0.96 \\
\hline & $\pm 0 \cdot 64$ & \pm 0.73 & $\pm 1 \cdot 14$ & \pm 0.93 & $\pm 0 \cdot 52$ & \pm 0.84 & $\pm 0 \cdot 26$ & $\pm 1 \cdot 20$ \\
\hline \multirow{2}{*}{ Heat-stable toxin + loperamide } & $14 \cdot 27^{* * *}$ & $9 \cdot 16$ & $+5 \cdot 11^{* *}$ & $12 \cdot 73$ & $10 \cdot 39$ & +2.95 & $5 \cdot 85^{* * *}$ & $+3.08^{*}$ \\
\hline & \pm 0.65 & \pm 0.43 & \pm 0.83 & \pm 0.99 & $\pm 0 \cdot 56$ & \pm 1.07 & $\pm 0 \cdot 54$ & \pm 0.94 \\
\hline
\end{tabular}

Fluxes in $\mu \mathrm{mol}(\mu \mathrm{Eq}) / \mathrm{cm}^{2} / \mathrm{h} .+=$ net absorption. $-=$ net secretion. $\mathrm{ms}=$ mucosa to serosa flux. sm $=$ serosa to mucosa flux. Isc $=$ short-circuit current. $\mathrm{J}^{\mathrm{R}} \mathrm{Net}=$ residual ion flux. ${ }^{* * *} \mathrm{p}<0 \cdot 01 .{ }^{* *} \mathrm{p}<0 \cdot 02 .{ }^{*} \mathrm{p}<0 \cdot 05$. 
loperamide in our study and partly inhibited its antisecretory effect in Sandhu's study ${ }^{18}$; this suggests that opiate receptors may be involved. The observation that loperamide binds to opiate receptors in both brain and myenteric plexus of the guinea-pig ${ }^{24}$ supports this idea. We conclude that loperamide has opiate-like antisecretory effects when applied to mucosa stimulated by secretagogues, and that this effect on ion transport contributes to its antidiarrhoeal activity.

We are grateful to $\mathrm{Dr}$ B S Drasar for kindly providing the $E$. coli toxin preparations and to Janssen Pharmaceuticals Limited for financial assistance.

\section{References}

1 McKay JS, Linaker BD, Turnberg LA. The influence of opiates on ion transport across rabbit ileal mucosa. Gastroenterology 1981; 80: 279-84.

2 McKay JS, Linaker BD, Higgs NB, Turnberg LA. Studies of the antisecretory activity of morphine in rabbit ileum in vitro. Gastroenterology 1982; 82: 243-7.

3 Niemegeers CJE, Lenaerts FM, Janssen PAJ. Loperamide ( $R$ 18553) a novel type of antidiarrhoeal agent Part 2: in vivo parenteral pharmacology and acute toxicity in mice. Comparison with morphine, codeine and diphenoxylate. Arzneim Forsch 1974; 24: 1636-41.

4 Nakayama S, Yamasato T, Mizutani M. Effects of loperamide on the motility of the isolated intestine in guinea pigs, rats and dogs. Jpn J Smooth Muscle Res 1977; 13: 69-74.

5 Isaacs PET, Corbett CL, Riley AK, Hawker PC, Turnberg LA. In vitro behaviour of human intestinal mucosa. The influence of acetyl choline on ion transport. J Clin Invest 1976; 58: 535-42.

6 Ussing $\mathrm{HH}$, Zerahn $\mathrm{K}$. Active transport of sodium as the source of the electrical current in the short-circuited isolated frog skin. Acta Physiol Scand 1951; 220: 1388-96.

7 Field M, Fromm D, McColl I. Ion transport in rabbit ileal mucosa $\mathrm{I}$ : $\mathrm{Na}$ and $\mathrm{Cl}$ fluxes and short-circuit current. Am J Physiol 1971; 220: 1388-96.

8 Niemegeers CJE, Lenaerts FM, Janssen PAJ. Loperamide (R18553) a novel type of antidiarrhoeal agent. Part $\mathrm{I}$ : in vivo oral pharmacology and acute toxicity comparison with morphine, codeine, diphenoxylate and difenoxine. Arzneim Forsch 1974; 24: 1633-36.
9 Awouters F, Neimegeers CJE, Kuyps J, Janssen PAJ. Loperamide antagonism of castor oil induced diarrhoea in rats: a quantitative study. Arch Int Pharmacodyn Ther 1975; 217: 29-37.

10 Karim SMM, Aidakan PG. The effect of loperamide on prostaglandin induced diarrhoea in rat and man. Prostaglandins 1977; 13: 321-31.

11 Galambos JT, Hersh T, Spalding S, Wenger J. Loperamide: a new antidiarrhoeal agent in the treatment of chronic diarrhoea. Gastroenterology 1976; 70: 1026-29.

12 Tytgat GN, Huibregtse K, Meuwissen SGM. Loperamide in chronic diarrhoea and after ileostomy. A placebo controlled double blind crossover study. Arch Chir Neerl 1976; 28: 13-20.

13 Mainquet P, Fiasse R. Double blind placebo-controlled study of loperamide (Imodium) in chronic diarrhoea caused by ileocolic disease or resection. Gut 1977; 18: 575-79.

14 Tytgat GN, Huibregtse K. Loperamide in ileostomy output - placebo controlled double blind crossover study. Br Med J 1975; 2: 667.

15 Van Neuten JM, Janssen PAJ, Fontaine J. Loperamide (R18553) a novel type of antidiarrhoeal agent. Part 3: In vitro studies on the peristaltic reflex and other experiments on isolated tissues. Arzneim Forsch 1974; 24: $1641-45$.

16 Kramer P. Effect of antidiarrhoeal and antimotility drugs on ileal excreta. Am J Dig Dis 1977; 22: 327-32.

17 Beubler E, Lembeck F. Inhibition of stimulated fluid secretion in the rat small and large intestine by opiate agonists. Arch Pharmacol 1979; 306: 113-18.

18 Sandhu BK, Tripp JH, Candy DCA, Harries JT. Loperamide: studies on its mechanism of action. Gut 1981; 22: 658-62.

19 Dobbins J, Racusen L, Binder HJ. The effect of enkephalin on ion transport in the rabbit ileum. J Clin Invest 1980; 66: 19-28.

20 Kachur JH, Miller RJ, Field M. Control of guinea pig intestinal electrolyte secretion by a $\delta$-opiate receptor. Proc Natl Acad Sci USA 1980; 77: 5: 2753-56.

21 Kimberg DV, Field M, Johnson J, Henderson A, Gershon E. Stimulation of intestinal adenyl cyclase by cholera enterotoxin and prostaglandins $J$ Clin Invest 1971; 50: 1218-30.

22 Evans DJ, Chen LC, Curlin GT, Evans DG. Stimulation of adenyl cyclase by Escherischia coli enterotoxin. Nature New Biol 1972; 236: 137-8.

23 Field M, Grat LH, Laird WJ, Smith PL. Heat stable enterotoxin of E. coli in vitro: effects on guanylate cyclase activity, cyclic GMP concentrations and ion transport in small intestine. Proc Natl Acad Sci USA 1978; 75: 2800-04.

24 Mackerer CR, Clay GA, Dajani EZ. Loperamide binding to opiate receptor sites in brain and myenteric plexus. J Pharmacol Exp Ther 1976; 199: 131-40. 